\title{
Analisis Kegunaan Website Kementerian Agama Provinsi DIY dan Provinsi Riau
}

\author{
M. Rafi, Achmad Nurmandi, Syed Agung Afandi
}

\begin{abstract}
Master of Government Affairs and Administration, Jusuf Kalla School of Government, Universitas Muhammadiyah Yogyakarta, Jl. Brawijaya, Kasihan, Bantul, Yogyakarta 55183, Indonesia, dan Department of Government Science, Faculty of Social and Political Sciences, Universitas Abdurrab, Jl. Riau Ujung No 73 Pekanbaru, Riau, Indonesia m.rafi.psc19@mail.umy.ac.id, nurmandiachmad@gmail.com, syedagungafandi@gmail.com
\end{abstract}

Masuk tanggal : 14-01-2020, revisi tanggal : 08-04-2020, diterima untuk diterbitkan tanggal : 16-04-2020

\begin{abstract}
At present, the usefulness of the website is seen only as a complement to the services of government agencies, many Ministry of Religion websites have an attractive appearance, but the quality of the information content presented on the website is not always updated. This study aims to analyze the use of the website of the Ministry of Religion of the Special Province of Yogyakarta and Riau Province. The research method used in this study is a qualitative research method to explore a case with data analysis techniques using the help of Nvivo12 Plus software. The results showed that in general the two websites both already have website content that refers to regulations, but in terms of the quality of presenting data, the website of the Ministry of Religion of Riau Province is considered better and meets 3 (three) website usability criteria, namely: Accessibility related to availability and ease of users to access content from a website can be seen from the comparison in terms of ease in understanding the appearance of the number of visitors between the two websites of the Ministry of Religion. second, Easy of use is related to the effort or effort made to use a website or how easily a website can be seen and differences in the availability of data that is still empty in some website columns, and third, namely Customization and Personalization relating to a website that provides content or content dynamic looks of the level of popularity of news on the website.
\end{abstract}

Keywords: analysis, website usability, Ministry of Religion

\begin{abstract}
Abstrak
Saat ini, kegunaan dari websiteterlihat hanya sebagai pelengkap dari pelayanan lembaga pemerintahan saja, banyak websiteKementerian Agama yang memiliki tampilan yang menarik, namun kualitas isi informasi yang disajikan di website tidak selalu di perbaharui. Penelitian ini bertujuan untuk menganalisis kegunaan websiteKementerian Agama Provinsi Daerah Istimewa Yogyakarta dan Provinsi Riau. Metode Penelitian yang digunakan dalam penelitian ini adalah metode penelitian kualitatif untuk mengeksplorasi suatu kasus dengan teknik analisis data menggunakan bantuan softwareNvivo12Plus. Hasil penelitian menunjukkan bahwa Secara umum kedua websitesama-sama telah memiliki konten websiteyang mengacu pada regulasi, namun dalam hal kualitas menyajikan data, website Kementerian Agama Provinsi Riau dinilai lebih baik dan memenuhi 3 (tiga) kriteria kegunaan websiteyaitu: Accessibility yang berkaitan dengan ketersediaan dan kemudahan pengguna untuk mengakses konten dari suatu website terlihat dari perbandingan dari sisi kemudahan dalam memahami
\end{abstract}


tampilan jumlah pengunjung antara kedua website Kementerian Agama. kedua,Easy of use berkaitan dengan usaha atau upaya yang dilakukan untuk menggunakan sebuah website atau seberapa mudah website dapat digunakan terlihat dan perbedaan ketersediaan data yang masih kosong dibeberapa kolom website, dan ketiga yaitu Customization and Personalization yang berkaitan dengan suatu website yang menyediakan konten atau isi yang dinamis terlihat dari tingkat popularitas sebuah berita diwebsite.

Kata Kunci: analisis, kegunaan website, Kementerian Agama

\section{Pendahuluan}

Memiliki website pada era informasi dan teknologi saat ini merupakan suatu proses yang mendorong masyarakat untuk lebih maju serta bertindak efektif dan efisien dalam menghadapi persaingan yang begitu kompeten, hal ini membuat teknologi yang semakin inovatif menjadi kebutuhan yang sangat penting, beberapa pandangan kehidupan masyarakat didorong untuk mengikuti perkembangan teknologi informasi dan komunikasi, baik itu dari sektor keamanan, hukum, ekonomi, pendidikan, sosial, politik, serta dalam bidang pemerintahan(Zulfahmi et al., 2019), di era informasi dan teknologi, kegunaan websitemenjadi hal yang sangat penting dan mendesak demi percepatan kemajuan pelayanan informasi bagi masyarakat, banyak hal-hal positif yang didapatkan dari adanya website yang dimiliki oleh suatu instansi dan lembaga-lembaga pemerintahan yang mesti didukung oleh adanya kemampuan sumber daya manusia yang berkualitas(Hanifah, 2016).

Basis interaksi manusia di era perkembangan teknologi informasi dan komunikasi saat ini adalah waktu, itulah sebabnya akses informasi menjadi kebutuhan manusia yang sangat mendesak. Pemerintah sebagai pelayan dari masyarakat harus bisa menyesuaikan dan mengaplikasikan e-government dalam tata kelola pemerintahan(Irawan, 2013), kegunaan website sebagai media e-government merupakan suatu instrumen yang sangat efektif dan efesien dalam mendukung keterbukaan informasi bagi masyarakat, kalangan bisnis, maupun lembaga-lembaga pemerintah(Zulfahmi et al., 2019).Keberhasilan pemerintah dalam menerapkan e-government sangat ditentukan oleh kualitas website dalam akses pelayanan dan keaktifan masyarakat dalam menggunakannya(Hardono, 2016), website resmi pemerintah tidak selalu efektif dalam menjadikan masyarakat yang selalu peduli terhadap informasi diwilayahnya, dibutuhkan pembaruan strategi pemerintah dalam memudahkan masyarakatnya untuk dapat menemukan informasi yang ada di daerahnya (Fauzi et al., 2017).

Dalam Peraturan Menteri Komunikasi dan Informatika Republik Indonesia No. Tahun 2017 tentang Penyelenggaraan Portal dan Situs Web Badan Pemerintahan dikatakan bahwa Portal Web atau Situs Web Badan Pemerintahan harus memiliki konten meliputi Profil Badan Pemerintahan, Kebijakan dan Produk Hukum, Pelaksanaan Program, Profil Layanan Publik, Layanan Aspirasi dan Pengaduan, Akun resmi media sosial serta Kontak Pengelola Situs Web. Kantor Wilayah Kementerian Agama Provinsi DIY merupakan sebuah instansi 
M. Rafi, Achmad Nurmandi, Syed Agung Afandi: Analisis Kegunaan Website Kementerian Agama Provinsi DIY dan Provinsi Riau

yang memiliki beberapa cabang dibawahnya, seperti Kementerian Agama Kabupaten Sleman, Bantul, Kulonprogo, Gunung Kidul dan Kota Yogyakarta. Kanwil Kemenag DIY berlokasi di Jalan Sukonandi No. 8 Kelurahan Semaki Kecamatan Umbulharjo Kota Yogyakarta, yang memiliki 71 Madrasah dan 78 KUA yang tersebar di 5 kabupaten/kota, begitu juga dengan Kantor Wilayah Kementerian Agama Provinsi Riau yang merupakan sebuah instansi yang besar dan memiliki banyak cabang yang ada dibawahnya seperti Kantor Wilayah Kementerian Agama Kabupaten/Kota dan Kantor Urusan Agama yang luas dan tersebar diberbagai daerah sekitar Provinsi Riau. Untuk itu penggunaan website sebagai media keterbukaan informasi dan komunikasi menjadi sangat penting sekali bagi masyarakat yang ingin mencari informasi dan komunikasi yang lebih efektif dan efesien serta lebih mudah dalam hal jarak, biaya, dan ketersediaan waktu.

Saat ini, peran dari websiteKementerian Agama terlihat hanya sebagai penambah dan pelengkap dari bagian pelayanan lembaga pemerintahan saja, banyak websiteKementerian Agama di Indonesia memiliki tampilan yang kreatif dan menarik, namun kualitas isi dari websitetersebut tidak mendeksripsikan secara lengkap terkait efektivitas pelayanan dan peningkatan pelayanan informasi bagi masyarakat, disamping itu berita yang disajikan diwebsite tidak selalu di upgrade, kecepatan dan kemudahan dalam mengakses informasi Kementerian Agama melalui websitebelum di evaluasi dan diawasi seusai ketentuan dan perundangundangan yang berlaku. Dengan performancewebsiteyang maksimal, yaitu baik dari sisi kemudahan dan kelengkapan informasi dalam websiteakan sangat membantu masyarakat dalam mencari informasi yang dibutuhkan hingga usability websitetersebut menjadi lebih baik(Hanifah, 2016), Penelitian ini bertujuan untuk melakukan perbandingan lebih jauh tentang perbedaanwebsiteusability Kementerian Agama Provinsi DIY dan website Kementerian Agama Provinsi Riau dalam memberikan kemudahan informasi bagi masyarakat serta menyajikan konten yang sesuai dengan regulasi yang telah ditetapkan.

Dalam menangani keluhan masyarakat berbasis E-government yang efektif, maka komitmen bersama dan kemampuan SDM tiap-tiap individual yang menanganinya tersebut merupakan faktor pendukung terwujudnya efektifitas E-government(Mukmin, 2017).Mekanisme dan prosedur yang transparan dalam pelaksanaan e-government merupakan suatu hal yang sangat penting, keterlibatan masyarakat serta dukungan finansial yang cukup sangat diperlukan(Hartana, 2015). Dalam pengembangan e-government, SDM yang ahli dalam teknologi informasi merupakan suatu hal yang sangat diperlukan, selain itu komitmen antara pimpinan dan karyawan dalam pemberian layanan yang maksimal kepada masyarakat juga termasuk bagian dari faktor pendukung lainnya (Rahmah \& Ranu, 2015).Dalam memberikan layanan informasi publik kepada masyarakat, maka kualitas websitee-government dari Pemerintah Daerah harus berfungsi dengan baik yakni didukung oleh hardware dan software yang mumpuni serta berdampak pada akses dan respon sistem web yang lebih cepat dan efesien(Beltahmamero, 2019).Inovasi Pemerintah dalam menjalankan $e$ government bisa dilakukan lewat pengembangan program kota cerdas command center sebagai media informasi publik, namun langkah ini bukanlah hal yang 
mudah, banyak hal yang harus disiapkan mulai dari mediasi, koordinasi, sosialisasi, kolaborasi, dan profesionalisme dibidang informatika dan komunikasi(Edam et al., 2018).Kehadiran e-government memberikan dimensi baru bagi pemerintah demi terwujudnya efisiensi pelayanan dan kepercayaan masyarakat(Hadijah, 2016).

Dalam layanan berbasis e-government, sosialisasi merupakan langkah awal yang harus ditempuh pemerintah dalam pengembangan teknologi informasi dan komunikasi(Nugroho, 2017).Implementasi e-government memiliki keterikatan dengan Good Governance yang menginginkan reformasi birokrasi dan kinerja pemerintahan yang lebih baik(Jauhari et al., 2015).Dalam ukuran dimensi PEGI (Pengukuran Elektronik Government Indonesia), kesiapan dan kemampuan pemerintah sangat dibutuhkan dalam pengelolaan informasi dan teknologi(Noveriyanto et al., 2018). Faktor-faktor yang mempengaruhi keberhasilan kebijakan implementasi e-government adalah perencanaan yang matang, kemampuan dan keterampilan, serta kepercayaan dan keyakinan dengan keberhasilan implementasi kebijakan(Siddique, 2016).Pada dasarnya, kesiapan dan peranan dari tiap-tiap stakeholders memiliki pengaruh yang kuat terhadap keberhasilan dari realisasi e-government(Putri \& Darmawan, 2018).Suatu negara dapat dikatakan maju apabila struktur politik yang dimilikinya memiliki sistem yang transparan, akuntabilitas, tidak adanya penyakit birokrasi yang korupsi di pemerintahan, serta ekektif dan efesien dalam memberikan pelayanan informasi kepada masyarakatnya(Hassan \& Lee, 2015).

Keberhasilan implementasi e-government dapat dilakukan dengan berbagai terobosan dan pembaruan yang sesuai dan berorientasi kepada masyarakat, serta koordinasi dan kolaborasi yang baik kepada pihak-pihak yang terlibat(Darmawan Napitupulu, 2015).Semua Critical Faktor Succes (CFS) berbasiskan meta-etnografi dapat membantu tiap-tiap organisasi pemerintah untuk selalu memperhatikan dan fokus dalam memastikan kesuksesan implementasi $e$ government(Napitupulu et al., 2017).Dalam proses pengembangan e-government di Indonesia, pemerintah harus berani merujuk kepada negara-negara maju yang telah berhasil, hal-hal yang perlu diperhatikan yaitu regulasi yang lebih spesifik, komunikasi terpadu antar lembaga pemerintah, meningkatkan sumber daya manusia dalam memahami konsep e-government, dan diikuti dengan peranan pemimpin yang menjadi kunci utamanya(Salsabila \& Purnomo, 2017).Konsep Egovernment mengharuskan tiap-tiap individu pemerintah dan karyawan dalam melaksanakan tugas pokok dan fungsinya memanfaatkan teknologi informasi dan komunikasi(Rubiyanto, 2019).

Pada level pemerintahan terendah seperti desapun diharuskan untuk mengembangkan potensi yang ada diwilayahnya dengan mempublikasikan secara online melalui website(Hartati \& Wijaya, 2017).Dalam rangka transformasi teknologi dan informasi, pegawai pemerintah harus memiliki niat yang kuat untuk mengadopsi e-government, dalam proses tersebut maka sikap merupakan bagian penting. Selain itu, perubahan budaya dan perilaku dapat mempengaruhi dan mendukung kinerja pemerintahan(Batara et al., 2017), pengaruh sosial dan fasilitas yang mumpuni memiliki dampak yang berarti bagi individu karyawan dalam proses pengadopsian E-government, peranan kepemimpinan dalam 
M. Rafi, Achmad Nurmandi, Syed Agung Afandi: Analisis Kegunaan Website Kementerian Agama Provinsi DIY dan Provinsi Riau

menjelaskan pentingnya transformasi ke era E-government sangat dinantikan oleh tiap-tiap karyawan(Alraja, 2016). Dalam mendukung keberhasilan implementasi e-government di Indonesia, validitas suatu konten merupakan faktor penentu keberhasilan(D. Napitupulu et al., 2018), sistem informasi e-government berbasis web merupakan suatu instrumen yang dapat memberikan layanan informasi yang cepat, tepat, dan akurat(Sriyati et al., 2015).E-government memiliki potensi dan pengaruh dalam mendukung Good Governance, akan tetapi teknologi ini belum tentu bisa diadopsi dan dikembangkan oleh tiap-tiap negara, karna butuh kesiapan yang matang dalam proses implementasinya(Hassan \& Lee, 2019).

Untuk mengukur tanda-tanda keberhasilan e-government dibutuhkan suatu kebijakan dan standar operasional prosedur dalam memantau penggunaan layanan online tersebut, namun keterlibatan tiap-tiap departemen pemerintah juga dapat dijadikan rujukan dalam menilai program implementasi E-government(Susanto, 2015).Minimnya kontribusi dari lembaga pengembangan dan penelitian dalam memberikan masukan kepada pemerintah memiliki pengaruh terhadap inkonsistensi implementasi E-government di Indonesia(Masyhur, 2017).Pada saat ini, implementasi E-government melalui media publik seperti website pemerintah dapat dikatakan memiliki banyak kekurangan, baik itu terkait masih selalu terjadinya trouble atau error website, jumlah nominal operator website yang mengelola sangat minim, kemampuan para pegawai dalam bidang teknologi informasi yang terbatas, serta belum ada regulasi tegas yang mengharuskan tiaptiap pegawai pemerintah secara keseluruhan mempelajari dan melaksanakan E-government(Fuadi \& Marom, 2016).

Penyediaan sarana-prasaranaE-government yang optimal dapat meningkatkan kualitas pelayanan kepada masyarakat dalam rangka pencegahan tindak pidana korupsi dilingkungan pemerintah itu sendiri(Ramdani, 2018). Penelitian (Utami et al., 2018),menemukan bahwa kualitas penggunaan website tidak memiliki dampak terhadap kepuasan pengguna website, namun kualitas suatu informasi dan kualitas interaksi sangat berpengaruh terhadap kepuasan pengguna website. Selanjutnya (Berlilana et al., 2017; Manik et al., 2017), memiliki hasil penelitian yang berbeda yakni peningkatan kualitas kegunaan akan berdampak positif terhadap kepuasan pengguna website. Selain itu, suatu website dapat digunakan sebagai sarana membangun relasi berbasis online(Wiratmo et al., 2017). Kepuasan pengguna website sangat dipengaruhi oleh kualitas layanan $e$ government. Dalam penggunaan website, diperlukan suatu regulasi dan pedoman bagi masyarakat untuk mengaksesnya(Haryani, 2016), usability secara umum berarti dapat dipergunakan dengan optimal, suatu website dapat dikatakan baik, apabila dalam penggunaannya mudah untuk dipelajari, mudah untuk diakses, serta memberikan kepuasan kepada para pengguna informasi(Ariantoro, 2015).Indikator dari usabilitywebsite adalahaccessibility, customization \& personalization, download speed, easy of use, errors, navigation, and size content(Hanifah, 2016). Untuk meningkatkan keterlibatan masyarakat yang lebih besar, Pemerintah sebagai subjek dari pelayanan publik diharapkan dapat menyajikan dan memberikan informasi yang akurat bagi yang membutuhkannya sesuai dengan ketentuan dan peraturan perundang-undangan yang berlaku(Zulfahmi et al., 2019). 
Beberapa penelitian yang ditemukan sebelumnya terlihat masih terbatas dan hanya berfokus pada analisis kepuasan dari pengguna website pemerintah dan efektivitas media website, dengan landasan tersebut, peneliti ingin melakukan perbandingan lebih jauh tentang perbedaan websiteusability Kementerian Agama Provinsi DIY dan website Kementerian Agama Provinsi Riau dalam memberikan kemudahan informasi bagi masyarakat serta menyajikan konten yang sesuai dengan regulasi yang telah ditetapkan. Konsep penelitian ini yaitu websiteusabilityyang berfokus pada 3 (tiga) kriteria dari kegunaan website yaitu accessibility yang dapat diartikan sebagai ketersediaan dan kemudahan pengguna untuk mengakses content dari suatu website, easy of use berkaitan dengan upaya yag dilakukan untuk menggunakan sebuah website atau seberapa mudah website dapat digunakan, serta customization and personalization adalahsuatu website yang menyediakan konten atau isi yang dinamis serta berisikan informasi yang telah disesuaikan untuk pengguna tertentu, hal ini dapat dilihat dari tingkat popularitas sebuah berita diwebsite dan juga jumlah pengunjung dari sebuah website(Hanifah, 2016).

\section{Metode Penelitian}

Penelitian ini menggunakan metode penelitian kualitatif, dalam(Mohajan, 2018),menjelaskan bahwa metode ini memungkinkan peneliti untuk mengeksplorasi untuk lebih memahami suatu fenomena, ini digunakan untuk mempelajari suatu kasus dalam konteks yang terbatas. Selain itu, penelitian kualitatif juga dapat menafsirkan suatu kasus tertentu untuk diamati dan dianalisis secara cermat dan teliti (Aspers \& Corte, 2019). Penelitian ini bertujuan untuk menganalisis bagaimana penggunaan kedua website pemerintah yakni website Kementerian Agama Provinsi DIY dan website Kementerian Agama Provinsi Riau.Hal yang mendasari peneliti memilih kedua website ini yaitu adanya rangkaian prestasi di tingkat nasional, websitewww.diy.kemenag.go.id pernah menjadi kontributor berita website teraktif pada tahun 2019, dan mendapatkan peringkat dua (2) pada pemberitaan bidang pengawasan yang diberikan oleh Inspektorat Jenderal Kementerian Agama RI tahun 2020. Sedangkan websitewww.riau.kemenag.go.idpernah mendapatkan peringkat satu (1) dalam menyajikan berita di konten website pada tahun 2010, serta mendapatkan peringkat tiga (3) dalam pengelolaan website yang diberikan oleh Pusat Informasi dan Kehumasan (Pinmas) Kementerian Agama RI pada tahun 2011.

Selanjutnya, Sumber data dalam penelitian ini berasal dari data primer dan data sekunder. Data primer adalah data yang diperoleh secara langsung dari sumber penelitian yaitu postingan berita dari kedua website tersebut. Sedangkan data sekunder merupakan data yang diambil dari bahan kepustakaan berupa referensi untuk mendukung sumber data primer seperti jurnal, buku, prosiding seminar nasional dan internasional untuk mendapatkan hasil yang relevan(Nur Azizah, 2018).Teknik Pengumpulan data yang digunakan dalam penelitian ini ialah dokumentasi dari kedua website resmi Kemenag DIY dan Kemenag Riau,serta beberapa media online yang sesuai. Pengumpulan data dengan studi dokumentasi diperlukan untuk mengetahui penyajian konten berita pada website. 
M. Rafi, Achmad Nurmandi, Syed Agung Afandi: Analisis Kegunaan Website Kementerian Agama Provinsi DIY dan Provinsi Riau

Data yang diperoleh dilakukan pengelolaan secara cermat dengan menggunakan Nvivo 12 Plus. Dengan adanya bantuan softwareNvivo 12 Plus dapat memudahkan peneliti, sehingga dimungkinkan untuk mengimpor dokumen langsung dari pengolah kata dengan mudah di layar (Welsh, 2002).Melalui coding analisis dari hasil fitur Ncapturedi website yang kemudian diproses menggunakan fitur tools explore crosstab Nvivo 12 Plus untuk menganalisis jumlah intensitas penyajian konten berita pada dua website tersebut.

\section{Hasil Penemuan dan Diskusi}

\section{Analisis Komparatif Konten Website}

Suatu pemerintahan yang baik haruslah diikuti dengan adanya ketersediaan informasi yang terbuka bagi masyarakat, banyak informasi yang harus diketahui oleh publik, untuk itu kemudahan akses suatu website merupakan suatu hal yang penting demi tercapainya transparansi informasi. Publik perlu tahu apa saja kegiatan yang sudah dilakukan oleh kementerian dan lembaga pemerintahan, seberapa sering kegiatan tersebut dilakukan, apakah hal tersebut menguntungkan atau melibatkan masyarakat(Puspitasari \& Harsasto, 2019), Artinya, website Kementerian Agama Provinsi DIY dan website Kementerian Agama Provinsi Riau harus melakukan publikasi informasi secara aktif.Jika di komparasikan antara dua website Kementerian Agama dalam hal kemudahan untuk diakses maka terlihat bahwa website Kementerian Agama Provinsi Riau lebih mudah untuk difahami dan tampilan konten yang lebih menarik dan sesuai dengan peraturan perundang-undangan yang berlaku, berikut ini ditampilkan analisis komparasi jumlah pengunjungwebsite Kementerian Agama di Provinsi DIY dan Provinsi Riau:

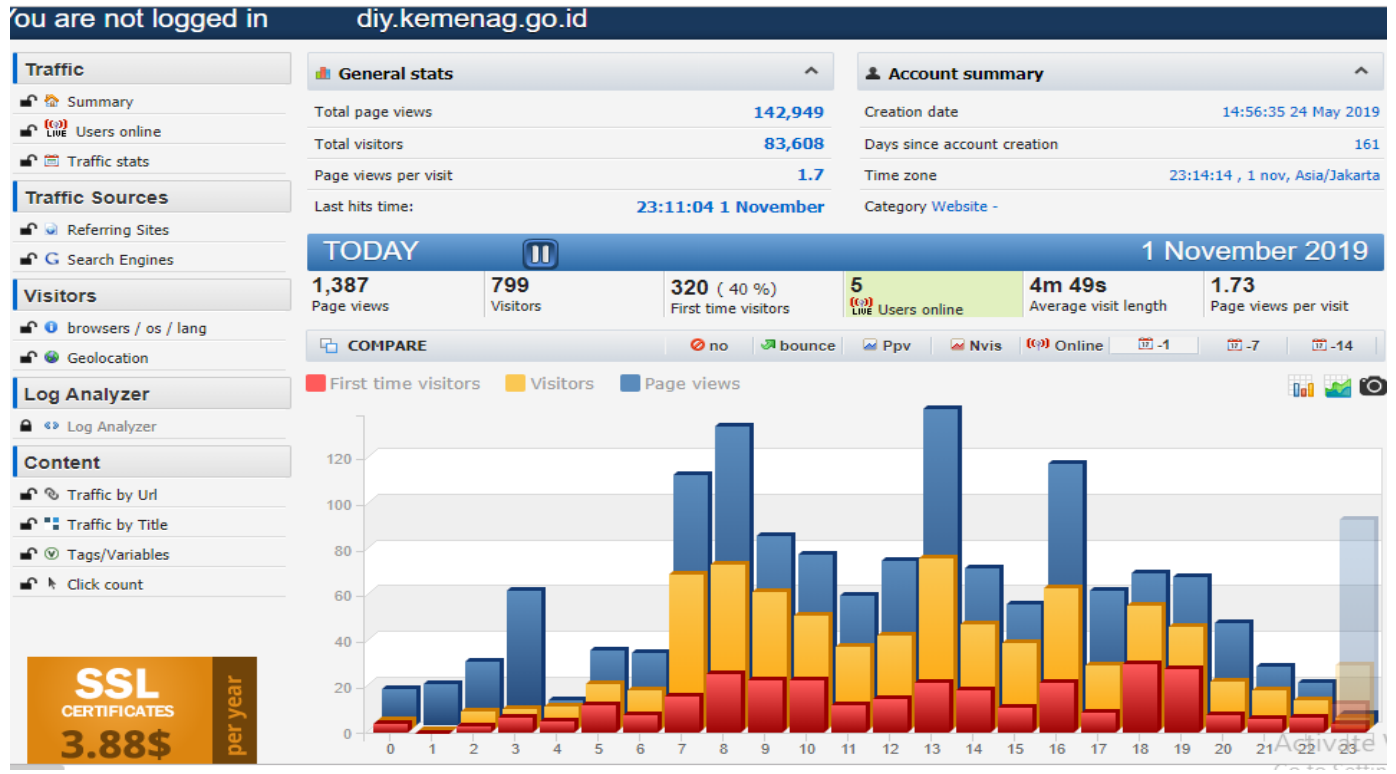

Gambar 1: Jumlah Pengunjung WebsiteKemenag DIY 01 November 2019

(Sumber: www.diy.kemenag.go.id) 


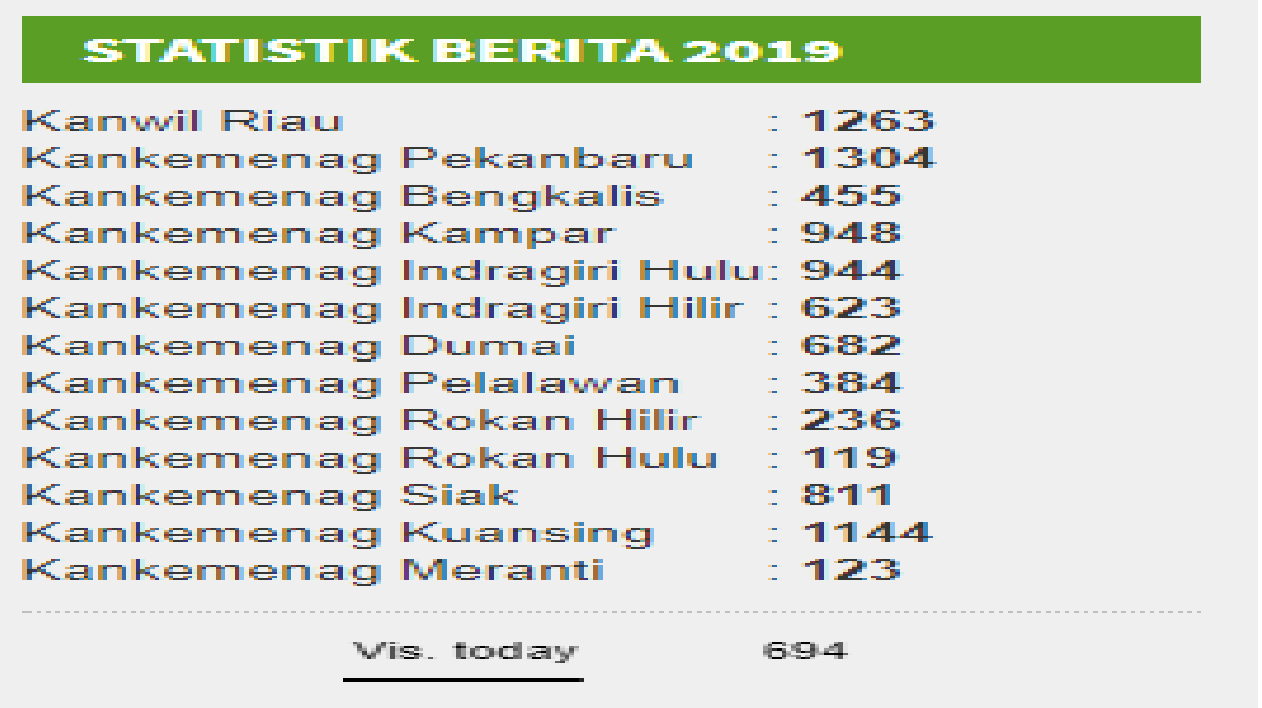

Gambar 2: Jumlah Pengunjung WebsiteKemenag Riau 01 November 2019 (Sumber: www.riau.kemenag.go.id)

Dari kedua gambar diatas terlihat bahwa dari sisi tampilan jumlah pengunjung, website Kementerian Agama Provinsi Riau lebih mudah dipahami dalam tampilan konten website jika dibandingkan dengan website Kementerian Agama DIY. Selain itu tampilan konten website yang diamanatkan oleh peraturan menteri komunikasi dan informatika no tahun 2017 tentang penyelenggaraan portal dan situs web badan pemerintahan yang sekurang-kurangnya memuat tampilan profil Badan Pemerintahan, kebijakan dan produk hukum Badan Pemerintahan, pelaksanaan program dan kegiatan lembaga Badan Pemerintahan, profil layanan publik pada Badan Pemerintahan, layanan aspirasi dan pengaduan, akun resmi media sosial Badan Pemerintahan, serta kontak pengelola situs, terlihat perbedaan dalam penyajian data, berikut ini analisis komparasi tampilan konten dari dua website Kementerian Agama:

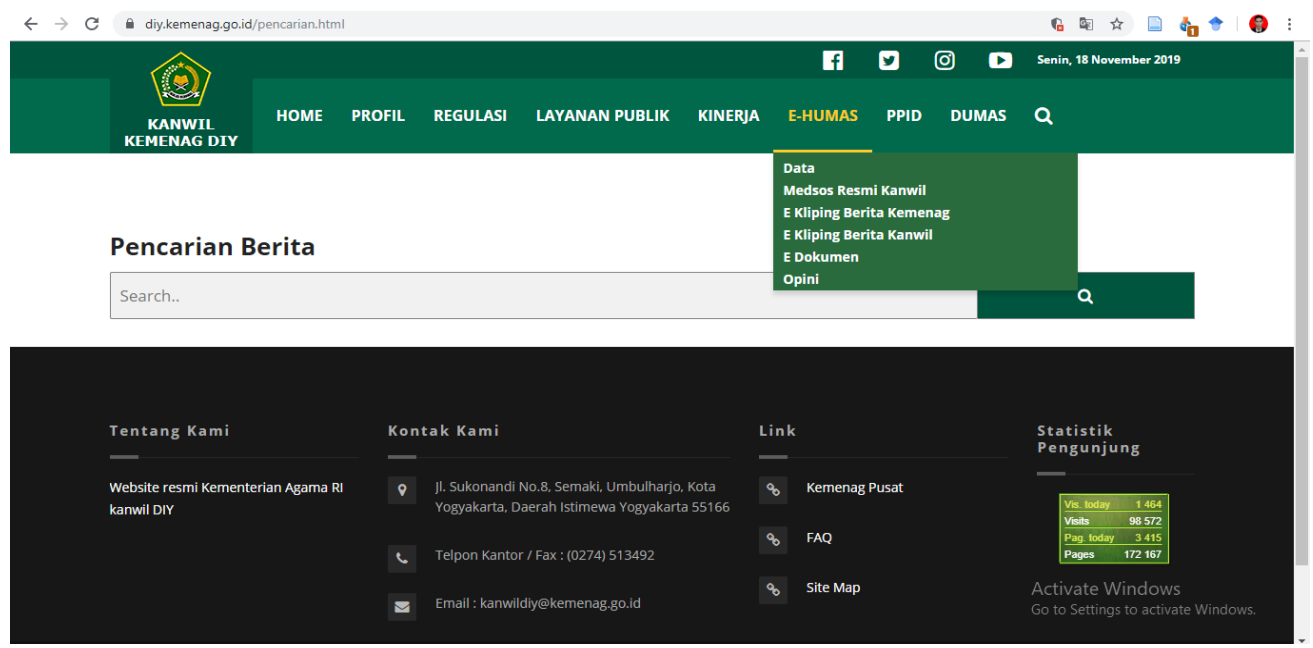

Gambar 3: Tampilan Konten Website Kemenag DIY

(Sumber: www.diy.kemenag.go.id) 


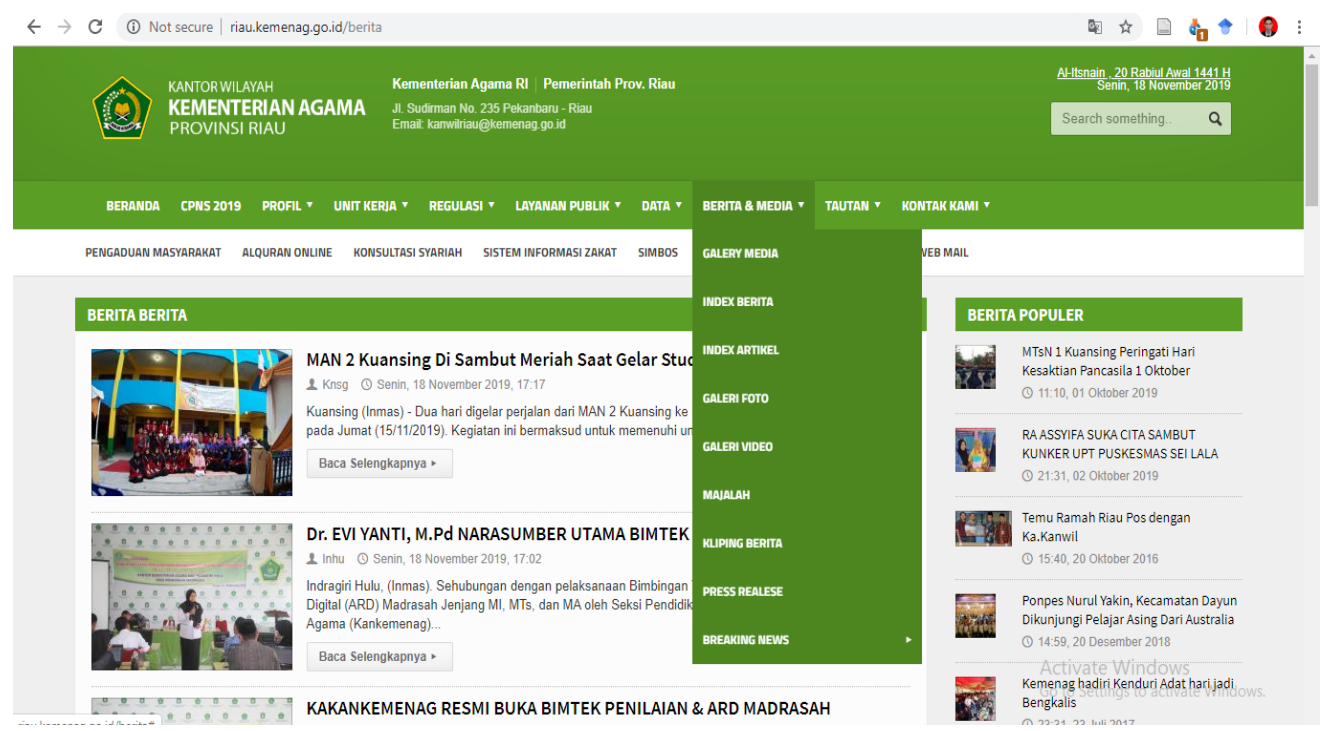

Gambar 4: Tampilan Konten Website Kemenag Riau (www.riau.kemenag.go.id)

Kedua tampilan konten website Kementerian Agama diatas dapatditelusuri bahwa kedua website sudah menyajikan konten website yang sesuai dengan amanat perundang-undangan, namun, suatu permasalahan yang ditemukan adalah isi dari website Kementerian Agama DIY tidak mudah untuk diakses dan masih terdapat beberapa data yang tidak bisa dicari disalah satu kolom website. Selanjutnya, website Kementerian Agama Riau memiliki persamaan dalam hal penyajian konten yang menarik namun terdapat perbedaan kualitas isi website yang lebih mudah diakses dan terdapat berbagai macam informasi maupun data dalam ketersediaan dan keterbukaan informasi yang ditampilkan didalam website. Selanjutnya akan ditampilkan beberapa keunggulan dan kelemahan dari masingmasing website:

Tabel 1. Analisis Komparatif Website Kementerian Agama

\begin{tabular}{|c|c|c|c|c|c|}
\hline No & Alamat Website & $\begin{array}{l}\text { Profil \& } \\
\text { Regulasi }\end{array}$ & Program Kerja & $\begin{array}{l}\text { Layanan } \\
\text { Publik }\end{array}$ & $\begin{array}{l}\text { Akun Resmi } \\
\text { dan Kontak }\end{array}$ \\
\hline 1. & diy.kemenag.go.id & $\begin{array}{l}\text { Tersedia } \\
\text { data } \\
\text { dikonten } \\
\text { website }\end{array}$ & $\begin{array}{l}\text { Tersedia } \\
\text { sebagian data } \\
\text { kegiatan. } \\
\text { namun banyak } \\
\text { data yang } \\
\text { masih kosong }\end{array}$ & $\begin{array}{l}\text { Tersedia di } \\
\text { konten } \\
\text { website }\end{array}$ & $\begin{array}{l}\text { Facebook, } \\
\text { Twitter, } \\
\text { Instagram, } \\
\text { Youtobe } \\
\text { (TelponKantor, } \\
\text { Email) }\end{array}$ \\
\hline 2. & riau.kemenag.go.id & $\begin{array}{l}\text { Tersedia } \\
\text { data } \\
\text { di konten } \\
\text { website }\end{array}$ & $\begin{array}{l}\text { Setiap } \\
\text { dibagian } \\
\text { kolom data } \\
\text { kegiatan tidak } \\
\text { ada data yang } \\
\text { kosong }\end{array}$ & $\begin{array}{l}\text { Tersediadi } \\
\text { konten } \\
\text { website }\end{array}$ & $\begin{array}{l}\text { Facebook, } \\
\text { Twitter, } \\
\text { Instagram, } \\
\text { Youtobe } \\
\text { (TelponKantor, } \\
\text { Email, } \\
\text { Whatsapp) }\end{array}$ \\
\hline
\end{tabular}

Sumber: Analisis Peneliti (2019) 
Tabel diatas menunjukan bahwa terdapat perbedaan dalam penyajian informasi dimana jika dibandingkan website Kementerian Agama Provinsi Riau lebih unggul dalam hal ketersediaan data yang disediakan, secara umum kedua website sama-sama telah memiliki konten website yang mengacu pada peraturan perundang-undangan, namun dalam hal kualitas menyajikan data website Kementerian Agama Provinsi Riau lebih unggul dan lengkap serta lebih mudah diakses dalam penyajian data informasi bagi masyarakat. Temuan ini sejalan dengan hasil penelitian(Zulfahmi et al., 2019) bahwa Efektivitas Media e-government dalam mendukung transparansi Informasi di Kantor Wilayah Kementerian Agama Provinsi Riau adalah melalui websitewww.riau.kemenag.go.id sebagai media yang efektif dan efesien dalam mendukung keterbukaan informasi bagi masyarakat.

\section{Analisis Komparatif Popularitas Berita di Website}

Suatu pemerintahan yang baik haruslah memenuhi prinsip keterbukaan informasi, karena tujuan dasar dari ketersediaan informasi publik adalah untuk mewujudkan pemerintahan yang terbuka, yaitu dengan meningkatkan konten website dan informasi publik untuk masyarakat(Puspitasari \& Harsasto, 2019). Dengan adanya website sebagai media promosi dan informasi, maka website juga dapat membantu dalam mempublikasikan berita, produk, dan kegiatan-keigatan lainnya yang ada diwilayah tersebut(Hasugian, 2018). Berikut ini akan ditampilkan gambar terkait hasil analisis komparatif terhadap suatu berita yang dominan pada masing-masing website:

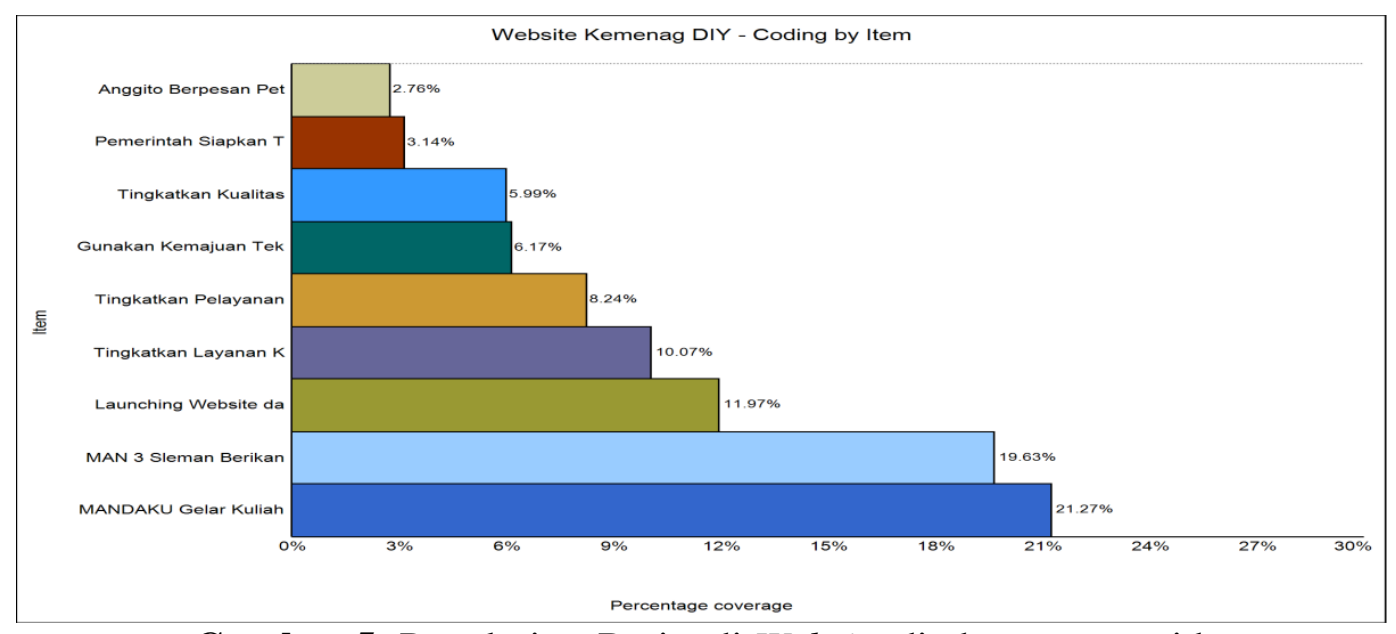

Gambar 5: Popularitas Berita di Website diy.kemenag.go.id

(Sumber: Hasil analisis peneliti menggunakan Nvivo12 Plus)

Berdasarkan gambar diatas terlihat bahwa berita yang paling dominan pada website Kementerian Agama Provinsi Daerah Istimewa Yogyakarta adalah rangkaian agenda kuliah tentang teknologi di Madrasah Aliyah Negeri 2 Kulon Progo (MANDAKU) dengan jumlah persentase 21,27\%. Revolusi industri 4.0 menjadi bukti dan proses dari pesatnya perkembangan teknologi dan digiltalisasi dalam berbagai aspek kehidupan, untuk itu, menjadi tantangan tambahan bagi 
M. Rafi, Achmad Nurmandi, Syed Agung Afandi: Analisis Kegunaan Website Kementerian Agama Provinsi DIY dan Provinsi Riau

sekolah-sekolah yang ada di Yogyakarta dalam mempersiapkan dan memastikan lulusan dari sekolahnya dapat tetap kompetitif dalam persaingan era revolusi industri dan teknologi, selanjutnya didalam website Kementerian Agama Provinsi Riau memiliki perbedaan dalam fokus pemberitaannya yaitu:

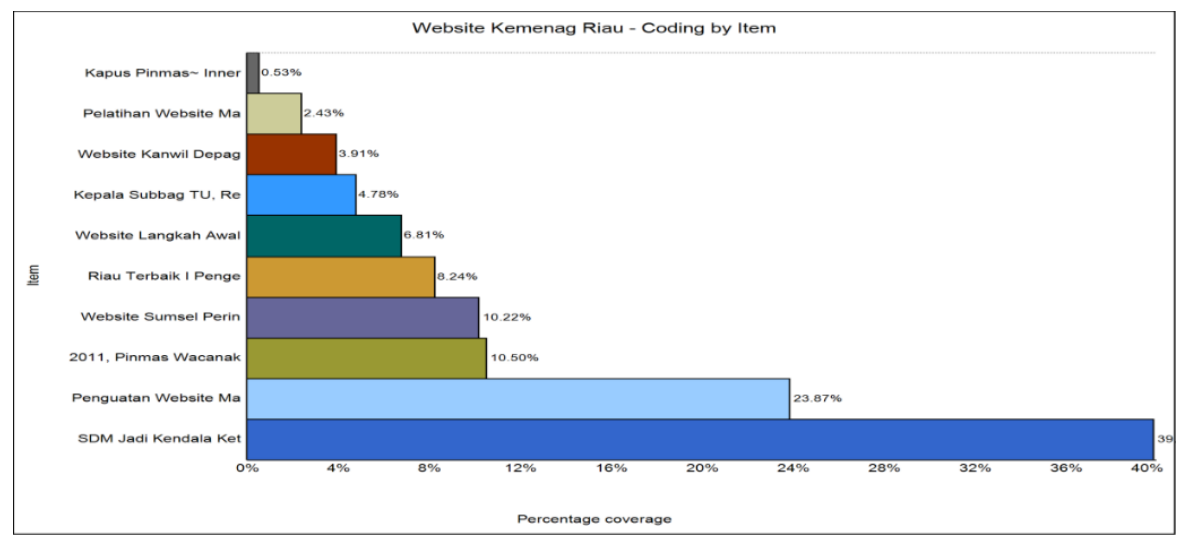

Gambar 6: Popularitas Berita di Website riau.kemenag.go.id

Sumber: Hasil analisis peneliti menggunakan Nvivo12 Plus

Pemberitaan yang paling mendominasi pada website Kementerian Agama Provinsi Riau adalah berita yang berkaitan dengan keterbatasan sumber daya manusia dalam pengelolaan website pemerintah yang memiliki persentase $39 \%$, Minimnya sumber daya manusia merupakan kendala dalam mengimplementasikan Undang-Undang No 14 Tahun 2008 tentang Keterbukaan Informasi Publik (KIP) melalui jaringan website. Dari analisis komparatif terhadap kedua website Kementerian Agama Provinsi DIY dan Provinsi Riau terlihat jelas bahwa setiap daerah memiliki kendala tersendiri dalam upaya peningkatan efektivitas usability website, pemberitaan diwebsite Kementerian Agama DIY lebih didominasi oleh upaya setiap sekolah dalam mempersiapkan generasi yang kompetitif di era teknologi informasi dan komunikasi, namun pemberitaan di website Kementerian Agama Provinsi Riau terlihat bahwa sumber daya manusia adalah penyebab kegagalan utama dalam pengelolaan website yang berkualitas, dan strategi yang harus dilakukan yakni mempersiapkan kualitas sumber daya manusia pengelola website yang lebih unggul dan mumpuni dalam pelayanan informasi publik.

Dalam penelitian ini, penyampaian informasi melalui pemberitaan di website yang selalu di update dan lengkapnya suatu informasi merupakan suatu langkah yang efektif dan efesien dalam memberikan pelayanan publik yang maksimal, kemudian, penggunaan teknologi informasi dan komunikasi berbasis website dapat memberikan inovasi bagi setiap instansi pemerintah dalam rangka peningkatan kualitas penggunaan website. Penelitian ini selaras dengan penelitian(Hanifah, 2016)yang menunjukan bahwa dengan melakukan perbandingan beberapa usability website dapat memberikan pengetahuan tentang posisi website berdasarkan usability-nya dimasyarakat dan membantu membuat website menjadi lebih baik agar berfungsi maksimal. 


\section{Simpulan}

Penelitian ini menemukan hasil analisis komparatif antara dua websiteKementerian Agama Provinsi DIY dan Provinsi Riau. Dalam hal kemudahan untuk diakses maka terlihat bahwa website Kementerian Agama Provinsi Riau lebih unggul dalam hal lebih mudah untuk dipahami dan tampilan konten yang lebih menarik serta relevan dengan produk hukum yang telah ditetapkan. Secara umum kedua websitesama-sama telah memiliki konten websiteyang mengacu pada regulasi, namun dalam hal kualitas menyajikan data, website Kementerian Agama Provinsi Riau lebih efektif dan dan memenuhi 3 (tiga) kriteria kegunaan website yakni: pertama,accessibility yang berkaitan dengan ketersediaan dan kemudahan pengguna untuk mengakses konten dari suatu website terlihat dari perbandingan dari sisi kemudahan dalam memahami tampilan jumlah pengunjung antara kedua website Kementerian Agama; kedua,easy of use berkaitan dengan usaha atau upaya yang dilakukan untuk menggunakan sebuah website atau seberapa mudah website dapat digunakan terlihat dari penyajian konten website yang sesuai dengan amanat perundangundangan, dan perbedaan ketersediaan data yang masih kosong dibeberapa kolom website; ketiga,customization and personalization yang berkaitan dengan suatu website yang menyediakan konten atau isi yang dinamis terlihat dari tingkat popularitas sebuah berita diwebsite Kementerian Agama.Penelitian lanjutan tentang efektivitas kegunaan websiteKementerian Agama Provinsi DIY dan Provinsi Riau perlu dilakukan analisis yang lebih mendalam terkait tujuh kriteria kinerja/kegunaan dari sebuah website. Rekomendasi penelitian juga ditujukan bagi para pengelola website Kementerian Agama Provinsi DIY dan Provinsi Riau untuk memaksimalkan efektifitas usability websitesebagai media keterbukaan informasi bagi masyarakat khususnya pada elemen easy of use.

\section{Ucapan Terima Kasih}

Kami ingin mengucapkan terima kasih kepada semua Dosen dan semua Civitas Akademika Program Studi Magister Ilmu Pemerintahan Universitas Muhammadiyah Yogyakarta yang telah memberikan pengarahan dan mendukung penelitian ini.

\section{Daftar Pustaka}

Alraja, M. N. (2016). The Effect Of Social Influence And Facilitatingconditions On E-government Acceptancefrom The Individual Employees' Perspective. Polish Journal Of Management Studies, 14(2), 18-27. Https://Doi.Org/10.17512/Pjms.2016.14.2.02

Ariantoro, T. R. (2015). Penerapan Metode Usability Pada Sistem Informasi Pelayanan Pelanggan (Studi Kasus: Website Pdam Tirta Musi Palembang). Jurnal Informanika, 2(1), 1-9.

Batara, E., Nurmandi, A., Warsito, T., \& Pribadi, U. (2017). Are Government Employees Adopting Local E-government Transformation?: The Need For 
M. Rafi, Achmad Nurmandi, Syed Agung Afandi: Analisis Kegunaan Website Kementerian Agama Provinsi DIY dan Provinsi Riau

Having The Right Attitude, Facilitating Conditions And Performance Expectations. Transforming Government: People, Process And Policy, 11(4), 612-638. Https://Doi.Org/10.1108/TG-09-2017-0056

Beltahmamero. (2019). Efektivitas Electronic Government Dalam Pelayanan Publik (Studi Kasus Pada Website Www.Bantulkab.Go.Id Di Pemerintah Kabupaten Bantul). Jurnal Mahasiswa UGM.

Berlilana, B., Suyanto, M., \& Luthfi, E. T. (2017). Pengaruh Penerapan Kualitas Kegunaan, Kualitas Informasi Dan Kualitas Interaksi Website Terhadap Kepercayaan Konsumen Hotel Di Kabupaten Banyumas. Jurnal IT CIDA, 3(2), 1-19.

Edam, N. S., Pangemanan, S., \& Kairupan, J. (2018). Efektivitas Program Cerdas Command Center Sebagai Media Informasi Masyarakat Dalam Rangka Pelayanan Publik (Studi Di Kantor Walikota Manado). JURNAL EKSEKUTIF, 1(1).

Fauzi, L. M., Ajizah, S. N., Kurnia, D., \& Yulianti, S. (2017). Efektivitas Egovernment Melalui Banserv Pada Kota Bandung. Jurnal Caraka Prabu, 1(2), 34-51.

Fuadi, A. I., \& Marom, A. (2016). Implementasi E-government Melalui Media Informasi Publik Berbasis Website Daerah Di Kabupaten Tegal. Journal Of Public Policy And Management Review, 5(4), 285-298-298. Https://Doi.Org/10.14710/Jppmr.V5i4.13625

Hadijah, S. (2016). Penerapan Efektivitas E-government Kecamatan Kaliorang Kabupaten Kutai Timur. Jurnal Penelitian Mahasiswa, 1(2), 1-11.

Hanifah, R. (2016). Perangkingan Usability Website Menggunakan Metode Multiple Criteria Decision Analisys. Jurnal Ticom, 5(1), 7-15.

Hardono, W. (2016). Analisis Kualitas Dan Efektivitas E-government Sebagai Media Pelayanan Publik Di Pemerintah Daerah Istimewa Yogyakarta Tahun 2015. Jurnal Ilmu Sosial Dan Ilmu Politik UMY, 1-15. Retrieved From Http://Repository.Umy.Ac.Id/Handle/123456789/8918

Hartana, M. (2015). Efektivitas Penerapan E-government Dalam Pencegahan Tindak Pidana Korupsi Di Lingkungan Pemerintahan Daerah. Jurnal Perhimpunan Mahasiswa Hukum Indonesia, 1(2), 60-87.

Hartati, S., \& Wijaya, R. (2017). Implementasi Web Government Sebagi Media Informasi Potensi Desa Sukaraja. Jurnal TAM (Technology Acceptance Model), 7(0), 61-66.

Haryani, P. (2016). Evaluasi Kualitas Layanan E-government Pemerintah Kota Yogyakarta Dengan Metode E-Govqual Modifikasi. Simposium Nasional RAPI XV-FT UMS, 8.

Hassan, M. H., \& Lee, J. (2015). Policymakers' Perspective Towards E-Gov Success: A Potent Technology For Attaining Good Governance In Pakistan. International Conference On Digital Information Processing And Communications, 272-281. Https://Doi.Org/10.1109/ICDIPC.2015.7323041

Hassan, M. H., \& Lee, J. (2019). Policymakers' Perspective About E-government Success Using AHP Approach: Policy Implications Towards Entrenching Good Governance In Pakistan. Transforming Government: People, 
Process And Policy, 13(1), 93-118. Https://Doi.Org/10.1108/TG-03-20180017

Hasugian, P. S. (2018). Perancangan Website Sebagai Media Promosi Dan Informasi. Journal Of Informatic Pelita Nusantara, 3(1), 82-86.

Irawan, B. (2013). Studi Analisis Konsep E-government: Sebuah Paradigma Baru Dalam Pelayanan Publik. Jurnal Paradigma, 2(1), 174-201.

Jauhari, A., Basri, H., \& Shabri, M. (2015). Penerapan Good Governanceberbasis E-government Dan Reformasi Birokrasi Dalam Rangka Meningkatkan Kinerja Satuan Kerja Pemerintah Aceh. Jurnal Administrasi Akuntansi : Program Pascasarjana Unsyiah, 4(3).

Manik, A., Salamah, I., \& Susanti, E. (2017). Pengaruh Metode Webqual 4.0 Terhadap Kepuasan Pengguna Website Politeknik Negeri Sriwijaya. Jurnal Elektro Dan Telekomunikasi Terapan, 4(1), 477-477. Https://Doi.Org/10.25124/Jett.V4i1.994

Masyhur, F. (2017). Penelitian E-government Di Indonesia: Studi Literatur Sistematis Dari Perspektif Dimensi Pemeringkatan E-government Indonesia (Pegi) E-government Research In Indonesia: Systematic. Jurnal IPTEK-KOM: Jurnal Ilmu Pengetahuan Dan Teknologi Komunikasi, 19(1), 51-62. Retrieved From Https://Jurnal.Kominfo.Go.Id/Index.Php/Iptekkom/Article/View/51-62

Mohajan, H. K. (2018). Qualitative Research Methodology In Social Sciences And Related Subjects. UTC Journal Of Economic Development, Environment And People, 7(1), 23-48. Retrieved From Https://Mpra.Ub.Uni-Muenchen.De/85654/1/MPRA_Paper_85654.Pdf

Mukmin, A. (2017). Efektifitas Penanganan Keluhan Masyarakat Berbasis Egovernment (Studi Tentang Unit Pelayanan Informasi Dan Keluhan (UPIK) Kota Yogyakarta Tahun 2015. Skripsi Jurusan Ilmu Pemerintahan $U M Y$.

Napitupulu, D. (2015). Kajian Faktor Sukses Implementasi E-government Studi Kasus: Pemerintah Kota Bogor. Jurnal Sistem Informasi, 5(3), 229-236. Https://Doi.Org/10.24089/J.Sisfo.2015.03.009

Napitupulu, D., Sensuse, D. I., \& Sucahyo, Y. G. (2017). Critical Success Factors Of E-government Implementation Based On Meta-Ethnography. International Conference On Cyber And IT Service Management, 1-6. Https://Doi.Org/10.1109/CITSM.2017.8089300

Napitupulu, D., Syafrullah, M., Rahim, R., Amar, A., \& Sucahyo, Y. G. (2018). Content Validity Of Critical Success Factors For E-government Implementation In Indonesia. IOP Conference Series: Materials Science And Engineering, 352(1). Https://Doi.Org/10.1088/1757899X/352/1/012058

Noveriyanto, B., Nisa, L. C., Bahtiar, A. S., Sahri, S., \& Irwansyah, I. (2018). Egovernment Sebagai Layanan Komunikasi Pemerintah Kota Surabaya (Studi Kematangan E-government Sebagai Layanan Komunikasi Government To Government, Government To Citizen, Government To Business). Profetik: Jurnal Komunikasi, 11(1), 37-53. Https://Doi.Org/10.14421/Pjk.V11i1.1371 
M. Rafi, Achmad Nurmandi, Syed Agung Afandi: Analisis Kegunaan Website Kementerian Agama Provinsi DIY dan Provinsi Riau

Nugroho, S. A. (2017). Faktor-Faktor Penghambat Pelayanan Berbasis EGovernment Pada Pembayaran Pajak Kendaraan Bermotor Dengan Sistem Anjungan Transaksi Mesin Kantor Bersama Samsat Di Surabaya Timur. Jurnal Kebijakan Dan Manajemen Publik, 5(2), 8.

Nur Azizah, R. S. K. (2018). Melawan Radikalisme Melalui Website. Jurnal ASPIKOM, 3(5), 942-957.

Patrik Aspers, U. C. (2019). What Is Qualitative In Qualitative Research. Qualitative Sosiology, 42(2), 139-160. Https://Doi.Org/Https://Doi.Org/10.1007/S11133-019-9413-7

Puspitasari, A. E., \& Harsasto, P. (2019). Penerapan Transparansi Melalui Website (www.jakarta.go.id) Pemerintah Provinsi Dki Jakarta (Periode Tahun 2017-2018). Journal Of Politic And Government Studies, 8(2), 91100.

Putri, N. Aslamaturrahmah D., \& Darmawan, E. (2018). E-Readiness Provinsi Kepulauan Riau Dalam Penerapan E-government (Studi Terhadap Kepri Smart Province). KEMUDI : Jurnal Ilmu Pemerintahan, 3(1), 173-192.

Rahmah, S. U., \& Ranu, M. E. (2015). Efektivitas Kerja Pegawai Dalam Menerapkan E-Office Untuk Mendukung E-government Dalam Kegiatan Korespondensi Kedinasan Di Fakultas Ekonomi Universitas Negeri Surabaya. Jurnal Universitas Negeri Surabaya, 20.

Ramdani, E. M. (2018). Analisis Efektivitas Pelaksanaan E-government Di Tingkat Kelurahan. Sawala: Jurnal Administrasi Negara, 6(1), 31. Https://Doi.Org/10.30656/Sawala.V6i1.520

Rubiyanto, R. (2019). Implementasi Kebijakan E-government Pada Badan Perencanaan Pembangunan Daerah Kabupaten Nganjuk. Jurnal Mediasosian: Jurnal Ilmu Sosial Dan Administrasi Negara, 2(1). Https://Doi.Org/10.30737/Mediasosian.V2i1.205

Salsabila, L., \& Purnomo, E. P. (2017). Establishing And Implementing Good Practices E-government (A Case Study: E-government Implementation Between Korea And Indonesia). Asean/ Asia Academic Society International Conference (Aasic), 5, 221-229.

Siddique, W. (2016). Critical Success Factors Affecting E-government Policy Implementation In Pakistan. Journal Of Edemocracy And Open Government, 8(1), 102-126. Https://Doi.Org/10.29379/Jedem.V8i1.398

Sriyati, Fiqih Satria, Sri Hartati, S. (2015). Pemanfaatan E-government Sebagai Media Promosi Di Bidang Pariwisata Ekonomi Kreatif (Studi Kasus: Dinas Pariwisata Ekonomi Kreatif, Kabupaten Pesawaran). Jurnal STMIK Pringsewu Lampung, 80-87.

Susanto, T. D. (2015). Measuring E-government Implementation Program: A Case Study Of Surabaya City, Indonesia. International Journal of Information Systems And Engineering, 3(1), 151-159. Https://Doi.Org/10.24924/Ijise/2015.11/V3.Iss1/151.159

Utami, L. A., Ishaq, A., \& Maulidiyah, N. (2018). Analisa Pengaruh Kualitas Website PPDB Terhadap Kepuasan Pengguna. Jurnal \& Penelitian Teknik Informatika, 3(1), 31-37. Https://Doi.Org/10.33395/Sinkron.V3i1.10146

Welsh, E. (2002). Dealing With Data: Using Nvivo In The Qualitative Data 
Analysis Process. Forum: Qualitative Social Research Sozialforschung, $3(2), 9$.

Wiratmo, L. B., Irfan, N., \& Kuwatono, K. (2017). Website Pemerintah Daerah Sebagai Sarana Online Public Relations. Jurnal ASPIKOM, 3(2), 326-339.

Zulfahmi, Muhammad Badri, L. S. (2019). Efektivitas Media E-government Dalam Mendukung Transparansi Informasi Di Kantor Wilayah Kementerian Agama Provinsi Riau. Jurnal Riset Mahasiswa Dakwah Dan Komunikasi, 1(1), 1-11. 